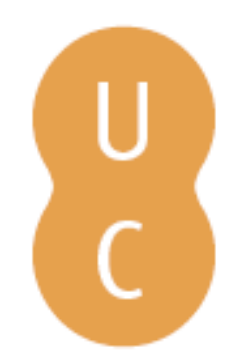

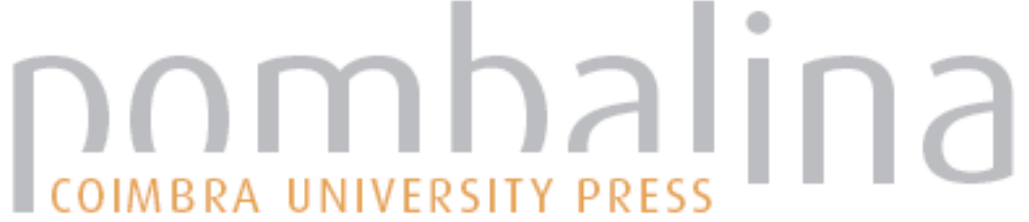

\section{De herói a anti-herói: a caracterização da personagem José Dirceu na revista Veja}

Autor(es): $\quad$ Vieira, Aletheia Patrice Rodrigues; Guazina, Liziane Soares

Publicado por: Imprensa da Universidade de Coimbra

URL

persistente: URI:http://hdl.handle.net/10316.2/41351

DOI: $\quad$ DOI:https://doi.org/10.14195/978-989-26-1324-6_10

Accessed : $\quad$ 26-Apr-2023 14:11:00

A navegação consulta e descarregamento dos títulos inseridos nas Bibliotecas Digitais UC Digitalis, UC Pombalina e UC Impactum, pressupõem a aceitação plena e sem reservas dos Termos e Condições de Uso destas Bibliotecas Digitais, disponíveis em https://digitalis.uc.pt/pt-pt/termos.

Conforme exposto nos referidos Termos e Condições de Uso, o descarregamento de títulos de acesso restrito requer uma licença válida de autorização devendo o utilizador aceder ao(s) documento(s) a partir de um endereço de IP da instituição detentora da supramencionada licença.

Ao utilizador é apenas permitido o descarregamento para uso pessoal, pelo que o emprego do(s) título(s) descarregado(s) para outro fim, designadamente comercial, carece de autorização do respetivo autor ou editor da obra.

Na medida em que todas as obras da UC Digitalis se encontram protegidas pelo Código do Direito de Autor e Direitos Conexos e demais legislação aplicável, toda a cópia, parcial ou total, deste documento, nos casos em que é legalmente admitida, deverá conter ou fazer-se acompanhar por este aviso. 



\title{
DE HERÓI A ANTI-HERÓI: \\ A CARACTERIZAÇÃo dA PERSONAGEM JOSÉ DIRCEU NA REVISTA VEJA
}

\author{
Aletheia Patrice Rodrigues Vieira \\ Universidade de Brasília \\ Liziane Soares Guazina \\ Universidade de Brasília
}

A construção das personagens da narrativa jornalística

Ao fazer cruzamentos com as narrativas literárias, Mesquita (2003) enfatizou as relações entre o processo de construção das personagens jornalísticas e a rotina profissional dos repórteres. Para a maioria dos jornalistas, especialmente para aqueles que estão em atividade nas redações, compreender que pessoas reais, retratadas em textos noticiosos, são representações que têm por objetivo gerar efeitos de sentido nos destinatários das mensagens e, portanto, constituem-se figuras do discurso, como afirma Motta (2013), é a negação de valores-notícias como a objetividade, exatidão e isenção.

A ideia de que o jornalismo constrói personagens e de que o jornalista conta estórias, conforme propõe Tuchman (1993), é, em geral, vista com desconfiança pela comunidade jornalística, por se 
considerar que o objetivo do jornalismo é divulgar fatos reais, ouvindo todos os lados envolvidos e com descrição fiel dos acontecimentos que geraram a notícia. No entanto, ao se identificar elementos narrativos nas matérias jornalísticas e as estratégias discursivas do narrador que evidenciam suas intencionalidades, conforme propõe Motta (2013), é possível observar mais amiúde as escolhas narrativas dos jornalistas e de que forma eles moldam as representações sobre o mundo da política.

Nosso objetivo neste artigo é identificar quais características, adjetivações e funções são atribuídas ao ex-ministro da Casa Civil José Dirceu, enquanto personagem da narrativa jornalística da revista Veja durante três momentos históricos diferentes. Como veremos mais adiante, nossas análises serão realizadas a partir da Análise Crítica da Narrativa proposta por Motta (2013), a partir de Campbell (1997) e Propp (2001). Também discorremos brevemente sobre o escândalo político-midiático (Thompson, 2002) em função do envolvimento atribuído a Dirceu no Escândalo do Mensalão.

Escolhemos a revista Veja uma vez que, além de ser um dos semanários mais conhecidos no Brasil, é também uma publicação que tem acompanhado, de forma sistemática, a carreira pública de José Dirceu, desde o período de atuação no movimento estudantil, na década de 1960, passando por momentos de exercício de cargos no período do Governo Luiz Inácio Lula da Silva, até a cobertura sobre o chamado Escândalo do Mensalão e posterior julgamento pelo Supremo Tribunal Federal. Importante destacar que os textos de Veja, muitas vezes, apresentam caracterização mais detalhada das personagens da notícia e dos episódios relacionados a elas do que a cobertura geral dos jornais.

Sendo assim, é possível identificar nos textos de Veja características, adjetivações e funções da personagem Dirceu em quatro matérias que envolvem o ex-ministro em momentos distintos de sua carreira política, desde 1968 até o ano de 2005, quando estourou 
o Escândalo do Mensalão. São elas: "Destruição e Morte: por quê?" (edição 5/1968), "O Congresso Interrompido" (edição 6/1968), "O homem que faz a cabeça de Lula" (edição 1770/2002) e "Ele assusta o governo" (edição 1916/2005).

Partimos da hipótese de que a imagem de José Dirceu foi construída ao longo dos anos por Veja à semelhança do que descreve Campbell (1997) como "ciclo do herói"; numa trajetória marcada por fases, surpresas e reviravoltas. Porém, no lugar de herói, a revista atribuiu a Dirceu características de anti-herói.

A vida de José Dirceu, que ganhou notoriedade em 1968 como líder do movimento estudantil na ditadura militar, é marcada por reviravoltas que são relatadas pela revista desde aquele ano, quando coincidentemente foi criada. Passou de liderança estudantil a exilado político, de articulador da campanha de Lula a acusado, durante o Escândalo do Mensalão, de chefe de um esquema de compra de votos no Congresso Nacional para aprovação de matérias de interesse do governo de Luís Inácio Lula da Silva, ainda no primeiro mandato do ex-presidente. Todos esses episódios biográficos de Dirceu foram alvo de notícias em Veja.

Em 2005, Dirceu pediu demissão do cargo de ministro-chefe da Casa Civil e, meses depois, teve o seu mandato de deputado federal cassado pela Câmara dos Deputados. Em 2013, após ser condenado pelo Supremo Tribunal Federal por corrupção ativa e formação de quadrilha (o ex-ministro foi absolvido deste crime após julgamento de recursos), José Dirceu foi preso e hoje cumpre a pena em regime domiciliar. Não voltou à carreira política e nem a ocupar posições de destaque no Partido dos Trabalhadores - PT, de que foi presidente e atuou de forma decisiva na campanha que levou Lula à Presidência da República em 2002.

Se a vida pública de José Dirceu é repleta de reviravoltas, a cobertura dedicada a ele pela revista Veja tem se concentrado em enfatizar, muitas vezes, as características pessoais do ex-ministro, suas ações 
e rede de relações privadas e públicas. Para se compreender como Veja define e desenha a personagem Dirceu, é necessário partir da noção de que as notícias são narrativas factuais, que se propõem a relatar os fatos de maneira mais próxima possível do real e "procura estabelecer reações lógicas e cronológicas das coisas físicas e das relações humanas reais ou fáticas" (Motta, 2013: 89).

As narrativas fáticas ou de ficção estão presentes na literatura, seja em romances, contos, novelas, ou filmes, e geram efeito de verossimilhança (Gancho, 2002: 10). O leitor acredita no que lê, mesmo a história sendo imaginária. No caso do jornalismo, há entre o narrador e o destinatário um contrato cognitivo baseado na credibilidade que delega ao jornal e ao jornalista-narrador a autoridade e legitimidade para dizerem a verdade sobre fatos reais (Motta, 2013: 39).

A personagem é quem realiza a ação no curso das narrativas. Segundo Gancho (2002), é a responsável pelo desempenho do enredo. O protagonista é uma classificação de personagem, a exemplo de José Dirceu nas matérias de Veja que serão analisadas, e de acordo com Abdala Júnior (1995: 44), os conflitos se desenvolvem em torno dele pois é "o ponto de referência para as alianças e confrontos entre os personagens".

A partir das funções (ou papel desempenhado pelas personagens, de acordo com Propp, 2001), é possível identificar quem são os protagonistas e antagonistas e a estrutura utilizada nas matérias jornalísticas - principalmente quando se trata de política, onde o conflito é categoria estruturante da narrativa política (Guazina \& Motta, 2010).

Ao citar Carlos Reis (1995), Mesquita (2003: 131) aponta que a personagem pode ser realçada durante determinado momento de sua vida, mas isso pode ser modificado ao longo das emissões, e ela assim desaparecer ou se tornar subalterna: "A personagem é considerada um lugar ideologicamente marcado, área privilegiada de investimento de valores e visões de mundo". 
Mesquita (2003) aponta ainda que a criação de personagens é uma atividade estruturante das práticas e do discurso jornalístico, que se assemelha ao valor-notícia da personalização proposto por Traquina (1993). Ele explica que as abordagens sobre personagens podem ser operativas em áreas não-ficcionais, como a reportagem, inclusive na caracterização de políticos.

Conforme o autor, as personagens jornalísticas são pessoas reais inseridas na narrativa jornalística, principalmente quando assumem situações de liderança ou de idolatria, reconstruídas aos olhos do leitor: "a personagem existe no quadro de uma narrativa que torna plausível sua representação" (Mesquita: 2003: 132). Mesquita considera que essa representação é fragmentada e que os traços biográficos de figuras públicas, como os políticos, são selecionados pelo jornalismo; isto é, não se conhece delas senão aquilo que a mídia diz a seu respeito. Ele defende que a personagem jornalística é construída a partir dos critérios de escolha do autor sobre o que é proposto pelo real, quando ordena os dados de acordo com o objetivo da narrativa.

Mesquita (2003: 137) também faz um paralelo entre a construção de personagens e a política. Segundo ele, as transformações das instituições públicas refletem nas mudanças estruturais das notícias e reportagens: "a personagem jornalística é um elemento estruturante, não só da narrativa midiática, mas também do próprio sistema político". Aqui observamos a similaridade de ideias de Mesquita (2003) e Thompson (2002), quando consideram que as opções eleitorais têm sido baseadas no caráter de quem pretende alcançar um cargo público, ou seja, dependem da pessoa do candidato, e não de "determinados temas e interesses" (Mesquita, 2003: 137).

Ainda de acordo com Mesquita (2003: 140), a construção da personagem jornalística começa com a negociação entre fonte e jornalista ao longo da apuração e depende das informações que farão parte da notícia: documentos, testemunho de pessoas, observação e interpretação dos gestos dos personagens, bem como seus comportamentos 
e obras. Para o autor, o que dá unidade, coerência interna e forma final às personagens é a criatividade do jornalista.

Sendo assim, não seria possível acessar a verdade biográfica das pessoas retratadas e/ou representadas nas matérias jornalísticas, uma vez que as personagens presentes nos textos são, em parte, fruto da subjetividade de quem escreve.

Por outro lado, Motta (2007: 153) destaca que a construção da personagem não se dá apenas no texto, mas também fundamenta-se na reconstrução/recombinação de elementos, muitas vezes contraditórios sobre as personagens por parte do leitor: "Os receptores (sic) do jornalismo conhecem as figuras públicas através de fragmentos que delas veicula o jornalismo".

Porém, há de se levar em consideração que o que se conhece das figuras públicas é também decorrente, na maior parte das vezes, da cobertura jornalística. Como veremos a seguir, a construção de personagens políticos ocorre num contexto de escândalos político-midiáticos nem sempre favorável aos políticos profissionais.

\section{A reputação e o escândalo político-midiático}

Nas sociedades democráticas contemporâneas, como é o caso do Brasil, a mídia passou a ocupar um papel de destaque na cobrança por honestidade e ética na política, principalmente por meio da divulgação de fatos que, ao longo de diferentes coberturas, constituem-se em escândalos políticos.

Os meios de comunicação deram visibilidade aos fatos do dia a dia relacionados à política e aos políticos que antes eram inacessíveis ao grande público, diz Thompson (2002). De acordo com o autor, a definição de escândalo inclui o fato de certos tipos de transgressões serem realizados em sigilo e que, ao se tornarem públicos, "são suficientemente sérios para provocar uma resposta rápida” (p.40). 
Na comunidade jornalística, o escândalo é um dos motivos que favorece a busca pelo "furo": "uma conquista que está associada ao brilho profissional, razão justificada de vaidade pessoal e que fornece prestígio" (Traquina, 1993: 55). Já para Waisbord (2000), as coberturas que envolvem a descoberta de atos de corrupção na política dão mais prestígio ao jornalista do que denúncias de injustiças sociais. Segundo ele, para alguns profissionais, é mais fácil apurar e escrever sobre problemas evidentes do que sobre as entranhas do poder, que quase sempre são inacessíveis caso não haja investigações.

Portanto, o sistema político-midiático molda, ao longo do tempo, os critérios de confiança/desconfiança dos cidadãos na política. Diz Thompson que, por meio da confiança, lidamos com a incerteza ou risco das ações e decisões que dependem dos outros. Implica a quem confia, pressupõe a possibilidade do desapontamento: "A confiança, como a reputação, é um recurso que não se consome com o uso. Pelo contrário, quanto mais ela é usada, maior será o estoque de confiança" (Thompson, 2002: 303). Thompson reitera que, em alguns casos, existe mais preocupação com a honestidade ou com a vida privada do político do que com a sua capacidade técnica: "Podem ser fonte de profundo desapontamento e assombro pois podemos perceber que indivíduos não correspondem às expectativas que deles tínhamos" (Thompson, 2002: 119).

Como os políticos, em geral, dependem da visibilidade midiática para serem bem-sucedidos em suas carreiras, passam a enfrentar as consequências da visibilidade midiática, entre elas, a vulnerabilidade aos escândalos e as denúncias. A histórica baixa confiança nos políticos, aliada ao poder da mídia em tornar (in)visível o jogo político, contribui para a manutenção da própria desconfiança da população na política (Guazina, 2014).

Uma das principais características gerais dos escândalos, trazidas por Thompson (2002: 40), que pode ser aplicada ao escândalo do Mensalão e à situação vivenciada por José Dirceu ao longo da cobertura 
jornalística de Veja sobre o caso, é de que "a revelação e condenação das ações e acontecimentos podem prejudicar a reputação dos indivíduos responsáveis por eles". O autor explica que, ao longo de suas carreiras, alguns políticos acumulam capital simbólico dentro dos aspectos da ética e da honestidade e levam tempo para conquistar esse patamar. O envolvimento em um escândalo de corrupção pode destruir o poder, o capital simbólico e a reputação rapidamente.

Após contextualizarmos a construção da narrativa jornalística e das personagens das notícias no contexto dos escândalos políticos, vamos, a seguir, detalhar os aspectos metodológicos envolvidos na pesquisa.

\section{Aspectos Metodológicos}

É parte da Análise Crítica da Narrativa, elaborada por Motta (2013), a metodologia de identificação das características e funções dos personagens em narrativas jornalísticas. Ao se utilizá-la, assume-se que, a partir dessa identificação, o narrador pode traçar estratégias argumentativas para gerar efeito de sentido; no caso do jornalismo, o efeito de real, e assim convencer o destinatário da mensagem de que as informações relatadas são verdadeiras. A descrição como recurso de linguagem é, portanto, uma dessas estratégias.

A seguir, descreveremos as principais etapas de nosso processo de aplicação da Análise Crítica da Narrativa para esta pesquisa. Inicialmente, foi feita uma leitura geral das matérias para identificarmos como Veja se refere a José Dirceu em cada um dos momentos relatados nas matérias. Com base na análise de personagens proposta por Gancho (2002), foram identificadas as funções de José Dirceu em cada enredo (protagonista, antagonista ou secundário), sua descrição como personagem redonda (por meio da classificação das características físicas, psicológicas, sociais, ideológicas e morais) 
ou plana. Com a identificação das funções, foi possível traçar quais juízos de valor a revista atribui ao ex-ministro.

A partir das primeiras observações, definimos a hipótese de que a imagem de José Dirceu foi construída ao longo dos anos por Veja de maneira semelhante ao que propõe Campbell (1997) como o "Ciclo do Herói». Para o autor, o herói pode ser determinado pelas seguintes características: alguém que se destaca, é mais forte de que os outros seres ou possui poderes mágicos, capaz de salvar os fracos e oprimidos. Porém, ao contrário de um herói, Veja atribui a Dirceu características de anti-herói, conforme veremos a seguir.

A narrativa jornalística em torno de José Dirceu o apresenta como um personagem que exerce determinadas funções de acordo com o contexto histórico em que está inserido, principalmente, por ter tido destaque na política brasileira em vários momentos de sua trajetória, criando ao seu redor uma espécie de mito, o que é perceptível em relação à leitura das quatro matérias que retornam a assuntos do passado do personagem, já tratado em reportagens anteriores.

De acordo com Campbell, o ciclo do herói - semelhante aos resultados dos estudos de Propp - segue os seguintes padrões: nascimento, chamado, jornada aliada a uma luta norteada por sacrifícios e amor, capazes de revolucionar a vida do próprio herói e das pessoas a sua volta. A jornada é marcada por dificuldades que são superadas.

Em linhas gerais, eis algumas das constatações de Propp (2001): ao herói é feito o pedido para reparar um dano, ele aceita o desafio e decide ir; em seguida, ele é submetido ao ataque do inimigo ou antagonista; depois reage a esse ataque quando recebe poderes mágicos ou a ajuda de outros personagens para vencer o antagonista; mesmo após a vitória e o regresso, o herói sofre perseguições, consegue se salvar e reinicia sua busca até reparar o dano e ser reconhecido pelo feito.

O ciclo vivido pelo herói, de acordo com Campbell (1997) e suas funções traçadas por Propp (2001), é composto basicamente pelas 
seguintes fases (adaptado por Motta, 2011: 185) e que foram associadas à trajetória de Dirceu ao longo das quatro matérias analisadas:

- Partida, também nomeada como "chamado da aventura": é quando o herói segue o destino até a missão que lhe foi dada ou que ele assume pela necessidade de mudar alguma situação.

- Superação de dificuldades ao longo da missão: nesse momento ele pode receber a ajuda de seres mágicos para então voltar e completar a missão.

- Perseguição: consegue se salvar e reparar o dano.

- Retorno ou reintegração: dependendo de como a missão foi conquistada pode representar glória ou destruição do herói.

O anti-heroísmo também reúne essas fases, portanto, também o anti-herói pode passar por elas. Segundo Motta (2011), o anti-herói é marcado pela personalidade contraditória, sendo necessárias várias descrições psicológicas para que o leitor compreenda que também não se trata de um vilão. O anti-herói toma decisões e age baseado em suas condições físicas, pessoais e sociais, e abriga sentimentos como a culpa, o medo, a revolta. Motta (2011) considerou essas caracterizações ao analisar o anti-heroismo do personagem João de Santo Cristo, protagonista da música Faroeste Caboclo, da banda de rock nacional Legião Urbana.

\section{Caracterização de Dirceu em Veja: quatro momentos}

A seguir, destacaremos em quadros as principais caracterizações, adjetivações e funções da personagem Dirceu e os respectivos trechos em que aparecem nas quatro matérias de Veja analisadas. Como será possível observar, boa parte das caraterizações refere-se a aspectos pessoais do ex-ministro. 
Como mencionamos anteriormente, em 1968, ele atuou como líder estudantil em São Paulo e ganhou notoriedade com os protestos de resistência dos estudantes à ditadura militar nas ruas. É nesse contexto que estão inseridas: i) a matéria "Destruição e Morte: porquê?" (Veja, edição 5/1968, p. 14-21), que tratam da "Batalha da Rua Maria Antônia", quando os estudantes do Centro de Filosofia e Ciências Humanas da Universidade de São Paulo (USP) se confrontaram fisicamente com estudantes da Universidade Mackenzie, onde supostamente estavam infiltrados líderes de organizações da extrema-direita, entre elas, o Comando de Caça aos Comunistas (CCC); e a matéria: "O Congresso Interrompido" (Veja, edição 6/1968) que relata como se deu a prisão de José Dirceu e outros líderes estudantis após a polícia impedir a realização do $30^{\circ}$ Congresso da União Nacional dos Estudantes - UNE, em que Dirceu era um dos candidatos à presidência.

Na edição 5/1968, as principais funções e ações atribuídas a Dirceu ressaltadas são:

Quadro 1

\begin{tabular}{|l|l|}
\hline Função & Ações atribuídas pela revista \\
\hline Destaque como líder & $\begin{array}{l}\text { "José Dirceu e Luis Travassos) os dois líderes estudan- } \\
\text { tis mais importantes do Estado de São Paulo" (p.19). }\end{array}$ \\
\hline $\begin{array}{l}\text { Determinado a lutar contra } \\
\text { as forças conservadoras da } \\
\text { direita }\end{array}$ & $\begin{array}{l}\text { "Luis Travassos e Édson Soares, respectivamente, } \\
\text { presidente e vice-presidente da ex-UNE, somados } \\
\text { a José Dirceu, comandavam a resistência da } \\
\text { filosofia" (p.17). }\end{array}$ \\
\hline $\begin{array}{l}\text { Organizador das passeatas } \\
\text { e incentivador da violência } \\
\text { dos estudantes com } \\
\text { a polícia durante os } \\
\text { protestos. }\end{array}$ & $\begin{array}{l}\text { "José Dirceu, presidente da ex-UEE, conhecido } \\
\text { como organizador, providenciava pedras, garrafas, } \\
\text { rojões (...) comandando uma passeata em que } \\
\text { foram incendiadas quatro viaturas policiais" (p.19). }\end{array}$ \\
\hline $\begin{array}{l}\text { Após a batalha da Maria } \\
\text { Antônia, demonstrava can- } \\
\text { saço e fraqueza }\end{array}$ & $\begin{array}{l}\text { "São bons líderes? - José Dirceu e Luís Travassos } \\
\text { eram dois líderes fracos e fadigados. Nenhum (...) } \\
\text { parecia ter forças políticas nem capacidade de } \\
\text { liderança suficientes para decidir por todos os } \\
\text { estudantes brasileiros" (p.19). }\end{array}$ \\
\hline
\end{tabular}


Na mesma matéria, o repórter descreve também com riqueza de detalhes o espaço físico e o ambiente tenso entre os estudantes, diante dos confrontos por meio de ações de José Dirceu:

José Dirceu subiu em um monte de tijolos, cadeiras, corrimãos de escada e paralelepípedos, que serviam de barricada e fez um comício relâmpago. 'Não é mais possível mantermos militarmente a Faculdade, não nos interessa continuar aqui lutando contra o CCC, a FAC e o MAC, esses ninhos de gorilas. Um colega nosso foi morto. Vamos às ruas denunciar o massacre. A polícia e o exército de Sodré que fiquem defendendo a fina flor dos fascistas. Viva a UNE, abaixo a repressão. (Veja, edição 5/1968, p.19).

Na edição 6/1968, a principais características observadas foram:

Quadro 2

\begin{tabular}{|l|l|}
\hline Funções & Ações atribuídas pela revista \\
\hline $\begin{array}{l}\text { Um dos culpados pela } \\
\text { desordem causada pelo } \\
\text { Movimento Estudantil }\end{array}$ & $\begin{array}{l}\text { "Os rapazes e moças enrolados em cobertores } \\
\text { coloridos, no frio do começo da tarde de sábado } \\
\text { passado, não pareciam os perigosos líderes } \\
\text { estudantis do Brasil inteiro, presos durante o } \\
30^{\circ} \text { Congresso da ex-UNE, em Ibiúna" (p.12). }\end{array}$ \\
\hline Líder derrotado & $\begin{array}{l}\text { "José Dirceu, ex-presidente da ex-UEE paulista. } \\
\text { Dirceu - cabelo comprido, barba por fazer, olhar } \\
\text { cansado" (p. 12). }\end{array}$ \\
\hline Fugitivo da polícia & $\begin{array}{l}\text { "Os três líderes estudantis (José Dirceu, Luis } \\
\text { Travassos e Vladimir Palmeira) estavam com } \\
\text { prisão preventiva decretada, finalmente execu- } \\
\text { tada depois de muitas vezes terem enganado a } \\
\text { polícia" (p.12). }\end{array}$ \\
\hline
\end{tabular}

Pelo facto de as duas matérias terem sido em sequência, uma semana depois da outra, pode-se então considerar que, neste primeiro 
momento, Dirceu estaria passando pela primeira fase do ciclo do herói, quando foi chamado a cumprir a missão de resistir à Ditadura, mas esta foi interrompida quando foi preso.

Dentro da perspetiva de Gancho (2002), constata-se que José Dirceu é uma personagem redonda na narrativa das duas edições de Veja sobre o movimento estudantil publicadas em 1968 e também um dos protagonistas das ações. No Quadro 3 abaixo, estão as características predominantes nas duas edições, divididas em classificações, também propostas por Gancho (2002):

Quadro 3

\begin{tabular}{|l|l|}
\hline Características & \\
\hline Físicas & Cabelo e barba por fazer \\
\hline Psicológicas & Cansado e fraco \\
\hline Sociais & Líder Estudantil \\
\hline Ideológicas & Um radical de esquerda \\
\hline Morais & $\begin{array}{l}\text { Perigoso, incentivador de violência e } \\
\text { fugitivo da polícia }\end{array}$ \\
\hline
\end{tabular}

A matéria "O homem que faz a cabeça de Lula" (Veja, edição 1770/2002, pp. 46-52) discorre sobre a possibilidade de ascensão de José Dirceu ao poder por meio da eleição de Luís Inácio Lula da Silva nas eleições presidenciais de 2002. Nela, é feito um resgate histórico sobre o passado de José Dirceu, além de comparações e paralelos às atitudes e características atribuídas a personagem no passado e no presente. Podemos considerar que, ao fazer o cruzamento dessas informações, a revista pretende mostrar se há coerência entre as ações do ex-ministro durante a ditadura e no momento atual.

Veja anuncia também que ele pode ser um ministro estratégico de um eventual governo Lula. Na época, Dirceu era deputado federal pelo PT em São Paulo e presidente do partido. O texto é baseado 
em relatos históricos de José Dirceu - que foi entrevistado - e de outras pessoas que conviveram com ele no passado e conviviam no presente. No ciclo do herói, é possível afirmar que a matéria corresponderia à superação das dificuldades - que começaram na ditadura - e que Dirceu estaria prestes a completar sua missão, no caso, levar o PT ao poder.

Neste momento, Veja o descreve como um personagem importante para a história política do país, porém com o objetivo de desconstruir possíveis mitos heróicos. Um dos temas tocados em relação à desconstrução da personagem é o exílio de José Dirceu em Cuba, para onde foi após ter seu nome na lista de presos políticos que deveriam sair da prisão em troca do resgate do embaixador americano Charles Elbrik, em 1969. A revista levanta questões sobre o treinamento guerrilheiro que ele teria feito no país, que poderia ser utilizado em uma eventual volta ao Brasil caso integrasse a luta armada. Na matéria, o próprio Dirceu é citado como quem é contra esse método.

A vida real de José Dirceu é ainda mais espantosa de que as histórias que se criaram a respeito dele e é possível reconhecer no radical do passado muito dos traços do moderado de hoje (...) 'eu era contra o movimento estudantil mandar quadros para a guerrilha"” (Veja, edição 1770/2002, p. 47).

Na edição, Veja destaca que, no passado, durante o movimento estudantil, José Dirceu era cabeludo, rebelde, namorador, bonitão e falante. Um jovem radical, conhecido pela capacidade de organização e obsessão em controlar tudo, que comandou passeatas históricas e era referência entre os estudantes de sua geração.

Além do exílio em Cuba, outro assunto que ganha destaque é a clandestinidade. Após fazer plásticas no rosto, José Dirceu voltou ao Brasil em 1976 com outra identidade e casou com a empresária Clara Becker, que só descobriu quem o marido era, quando ele integrou 
a lista dos anistiados políticos da Ditadura em 1979, e precisou revelar o segredo.

Na edição 1770/2002, as principais funções e ações atribuídas a Dirceu ressaltadas são:

Quadro 4

\begin{tabular}{|c|c|}
\hline Funções & Ações atribuídas pela revista \\
\hline Centralizador e controlador & $\begin{array}{l}\text { "Na campanha petista à presidência } \\
\text { não se toma uma decisão sem o aval } \\
\text { de José Dirceu, que controla tudo com } \\
\text { mão de ferro" (p.46). }\end{array}$ \\
\hline $\begin{array}{l}\text { Se tornou um político da esquerda } \\
\text { moderada }\end{array}$ & $\begin{array}{l}\text { "Um ano antes da aliança do PT } \\
\text { com o PL, José Dirceu já dizia, em } \\
\text { conversas reservadas com capitães de } \\
\text { indústrias, que o vice de Lula seria } \\
\text { um empresário, ato que simbolizaria a } \\
\text { união capital-trabalho" (p.46). }\end{array}$ \\
\hline $\begin{array}{l}\text { Assim como na ditadura, continua } \\
\text { sendo organizador }\end{array}$ & $\begin{array}{l}\text { "É um leitor voraz de pesquisas e } \\
\text { planeja eventos da campanha (...) traça } \\
\text { organogramas e se gaba de administrar } \\
\text { o PT como uma empresa" (p.51) }\end{array}$ \\
\hline É misterioso & $\begin{array}{l}\text { "Da sua experiência na } \\
\text { clandestinidade, ele aprendeu a agir } \\
\text { nas sombras (...) tem uma agenda } \\
\text { repleta de encontros secretos" (p.51). }\end{array}$ \\
\hline Fez escolhas oportunas & $\begin{array}{l}\text { "Se não tivesse feito sua conversão a um } \\
\text { esquerdismo menos ortodoxo, não seria } \\
\text { o líder de um partido que agora disputa } \\
\text { a presidência da República" (p.52) }\end{array}$ \\
\hline Não teria amizades sólidas & $\begin{array}{l}\text { "O economista Paulo de Tarso } \\
\text { Venceslau, que saiu do PT em } 1997 \\
\text { (...), solta a língua quando fala de José } \\
\text { Dirceu. 'Ele tem fome de poder e seu } \\
\text { estilo é jogar uns contra os outros para } \\
\text { se manter por cima”" (p.51). }\end{array}$ \\
\hline
\end{tabular}

No Quadro 5 a seguir, com base na classificação de Gancho (2002), destacamos as características mais marcantes de José Dirceu na matéria da edição 1770/2002: 
Quadro 5

\begin{tabular}{|l|l|}
\hline Características & Características atribuídas pela revista \\
\hline Físicas (Passado) & Cabeludo e bonito \\
\hline Psicológicas & Centralizador e organizador \\
\hline Sociais & Deputado Federal e presidente do PT \\
\hline Ideológicas & Um esquerdista moderado \\
\hline Morais & $\begin{array}{l}\text { Age nas sombras e enganou sua } \\
\text { primeira mulher }\end{array}$ \\
\hline
\end{tabular}

Já a matéria "Ele assusta o governo" (Veja, edição 1916/2005, p. 57-62), número em que Dirceu é capa, repercute as acusações de Renilda Fernandes de Souza, mulher do publicitário Marcos Valério (acusado de ser operador financeiro do esquema do Mensalão) em depoimento à Comissão Parlamentar Mista de Inquérito - CPI dos Correios. A Comissão tinha como objetivo investigar o caso no âmbito do Congresso Nacional, e Renilda Fernandes de Souza teria testemunhado a presença de Dirceu em reuniões com o marido para tratar de financiamentos para campanhas eleitorais e compra de apoio político.

Podemos observar no Quadro 6 abaixo as funções da personagem Dirceu na matéria:

Quadro 6

\begin{tabular}{|l|l|}
\hline Funções & Ações atribuídas pela revista \\
\hline Acusado de articular o esquema do & "Em depoimento a CPI dos Correios, \\
mensalão & Renilda Santiago Fernandes de Souza, \\
& mulher do publicitário Marcos Valério \\
& disse que José Dirceu não só sabia \\
& de tudo como ainda se reuniu com \\
& representantes dos bancos envolvidos" \\
& (p.57) \\
\hline Frustrado & "O ex-ministro se considerava o \\
& sucessor natural de Lula",p.59 \\
\hline
\end{tabular}




\begin{tabular}{|l|l|}
\hline Arquivo vivo da política & $\begin{array}{l}\text { "Dirceu tem a memória boa e ruim do } \\
\text { governo Lula" p.58 }\end{array}$ \\
\hline Não queria ser acusado sozinho & $\begin{array}{l}\text { "'Fiz tudo com o conhecimento e o aval } \\
\text { do presidente', repete Dirceu, dando a } \\
\text { entender que, para se salvar, não hesitará } \\
\text { em chantagear o presidente Lula", p.58 }\end{array}$ \\
\hline $\begin{array}{l}\text { Ainda era preservado pelos colegas } \\
\text { de partido }\end{array}$ & $\begin{array}{l}\text { "Delúbio (Soares, tesoureiro do PT) } \\
\text { fez questão de preservar Dirceu em } \\
\text { seu depoimento à CPI, dizendo que o } \\
\text { ex-ministro não sabia nadica de nada } \\
\text { dos empréstimos bancários malandros } \\
\text { contraídos pelo PT" (p.58) }\end{array}$ \\
\hline Sentia que poderia ser traído & $\begin{array}{l}\text { "Dirceu não tem dúvidas de que ele é } \\
\text { uma espécie de troféu para a oposição } \\
\text { e que pode ser vítima de uma conspi- } \\
\text { ração de ex-aliados" (p.60) }\end{array}$ \\
\hline $\begin{array}{l}\text { Humilhado pela forma como } \\
\text { foi demitido da Casa Civil }\end{array}$ & $\begin{array}{l}\text { Jefferson em que ele aconselha Dirceu } \\
\text { a deixar o governo, foi chamado ao } \\
\text { gabinete do presidente 'acho melhor } \\
\text { você sair', disse Lula, de maneira } \\
\text { brusca" (p.60). }\end{array}$ \\
\hline
\end{tabular}

A seguir, destacamos as principais características de Dirceu no Quadro 7:

Quadro 7

\begin{tabular}{|l|l|}
\hline Características & Características atribuídas pela revista \\
\hline Físicas & Não aparecem \\
\hline Psicológicas & Pragmático, Ressentido e humilhado \\
\hline Sociais & $\begin{array}{l}\text { Demitido da Casa Civil, prestes a per- } \\
\text { der o mandato de deputado }\end{array}$ \\
\hline Ideológicas & Atende a interesses políticos \\
\hline Morais & $\begin{array}{l}\text { Acusado de chefiar um esquema de } \\
\text { corrupção }\end{array}$ \\
\hline
\end{tabular}

Entendemos que a matéria da edição 1916/2005 pode representar o fechamento do ciclo anti-heróico de José Dirceu nas quatro matérias 
analisadas (outros fatos se sucederam após as primeiras acusações contra Dirceu no escândalo do Mensalão) com o momento da possível vitória ou destruição do personagem.

\section{Considerações finais}

A partir da análise das funções, ações atribuídas e características de José Dirceu em quatro matérias de Veja, encontramos indícios de que, no período analisado, ele cumpre, como personagem da revista Veja, uma saga anti-heróica, tendo em vista que é retratado sob várias nuances, que ressaltam suas contradições inclusive de cunho pessoal e psicológico, e a possibilidade de ser derrotado/destruído.

Ainda que nossos resultados sejam preliminares, é possível inferir que a personagem José Dirceu descrita em Veja é alguém que desperta desconfiança dos que estão a sua volta e se adequou ideologicamente de acordo com o momento político que vivia. Suas principais características psicológicas, que, segundo a revista, se mantiveram desde a ditadura militar, seriam frieza, pragmatismo, capacidade centralizadora e de fazer qualquer coisa para se manter no poder. Ao se descrever o contexto em que o ex-ministro estaria em conflito com os companheiros de partido em função das acusações de envolvimento no Mensalão, Veja descreve, por exemplo, José Dirceu como alguém que não seria amigo de ninguém e que estava em atrito com o então presidente Luiz Inácio Lula da Silva.

Ao mesmo tempo, a revista apropria-se, mesmo que de forma involuntária, das fases atribuídas por Campbell aos heróis das narrativas ficcionais. Se a caracterização e as ações atribuídas reforçam aspectos negativos de Dirceu enquanto personagem de Veja, por outro lado, a associação às fases do herói ajuda a explicar o destaque da revista a Dirceu em diferentes momentos históricos e - por que 
não - o reconhecimento à liderança do ex-ministro enquanto ator político da história recente.

De qualquer maneira, seja para enfatizar características desabonadoras, seja para contar as peripécias e reviravoltas da biografia de Dirceu, ao enfatizar este personagem, Veja reforça a ideia de que o jornalismo, ao reunir e combinar fragmentos da vida real, torna-se ele mesmo o narrador que atribui valor de verdade às narrativas publicadas e importância às personagens políticas da contemporaneidade.

\section{REFERÊNCIAS BIBLIOGRÁFICAS}

ABDALA JUNIOR, B. (1995). Introdução à Analise de Narrativa. São Paulo: Scipione. CAMPBElL, J.O. (1997). Herói de Mil Faces. São Paulo: Cultrix.

GANCHO, C. V. (2002). Como analisar narrativas. São Paulo: Editora Ática.

GUAZINA, L. (2014). "Quando cultura política e subcultura jornalística andam de mãos dadas: a desconfiança na política em tempos de escândalos". Trabalho apresentado no $23^{\circ}$ Encontro Anual da Associação Nacional dos Programas de Pós-Graduação em Comunicação - Compós.

GUAZINA, L.; MOTTA, L. G. (2010). "O Conflito como categoria Estruturante da Narrativa Política: o caso do Jornal Nacional”, in Brazilian Journalism Research, v.6, pp.132-149.

MESQUITA, M. (2003). O quarto Equívoco - o poder dos media na sociedade contemporânea. Coimbra: MinervaCoimbra.

MOTTA, L. G. (2011). Análise Crítica da Narrativa. Brasília: Editora Universidade de Brasília.

MOTTA, L. G. (2011). "A narrativa mediada e a permanência da tradição: percurso de um anti-herói brasileiro", in Estudos de Literatura Contemporânea, n. ${ }^{3}$, julho/dezembro, pp.185-212.

PROPP, V. (2001). Morfologia do Conto Maravilhoso. São Paulo: CopyMarket.com. THOMPSON, J. (2002). O Escândalo Político: poder e visibilidade na era da mídia. Rio de Janeiro: Vozes. 
TUCHMAN, G. (1993). "A Objetividade como Ritual Estratégico: uma análise das noções de objetividade dos jornalistas", in TRAQUINA, N. (Org.). Jornalismo: questões, Teorias e Histórias. Lisboa: Vega, pp. 74-90.

TUCHMAN, G. (1993). "Contando estórias", in TRAQUINA, N. (Org.). Jornalismo: questões, Teorias e Histórias. Lisboa: Vega, pp. 258-262.

TUCHMAN, G. (1978). Making News. A Study in the Construction of Reality. New York: Free Press.

TRAQUINA, N. (Org.) (1993). Jornalismo: questões, Teorias e Histórias. Lisboa: Vega. VEJA, Destruição e Morte: porquê?, edição 5, 1968.

—, O Congresso Interrompido, edição 6, 1968.

—, O homem que faz a cabeça de Lula, edição 1770, 2002.

—, Ele assusta o governo, edição 1916, 2005.

WAISBORD, S. (2000). Watchdog Journalism in South America: news, accountability and democracy. New York: Columbia University Press. 